\title{
Szymon Askenazy - szkic do portretu historyka neoromantycznego
}

Szymon Askenazy jako jeden z najpoczytniejszych historyków polskich przełomu XIX i XX w. wciąż budzi zainteresowanie wśród badaczy. Szczególnie w ostatnich latach ukazało się sporo artykułów poświęconych jego twórczości naukowej i publicystycznej oraz szkole historycznej, jaką stworzył1 ${ }^{1}$. W mniej-

\footnotetext{
${ }^{1}$ M. Bucior, Przeglad publicystyki Szymona Askenazego do 1914 roku, "Annales Universitatis Mariae Curie-Skłodowska. Sectio F Historia" 1997/1998, vol. 52/53, s. 163-175; M. Bucior, Z genealogii Szymona Askenazego, "Biuletyn Żydowskiego Instytutu Historycznego” 1998, nr 4, s. 91-101; A. Kosicka-Pajewska, Szymon Askenazy i jego miejsce w historii, "Mazowieckie Studia Humanistyczne" 2002, nr 2, s. 145-153; A. Hinc, Z dziejów recepcji literatury historycznej w Polsce: fenomen "Księcia Józefa Poniatowskiego" Szymona Askenazego, w: Dzieje polityczne, kultura, biografistyka. Studia z historii XIX i XX wieku ofiarowane prof. Zbigniewowi Dworeckiemu, pod red. L. Trzeciakowskiego i P. Matusika, Poznań 2002, s. 165-180; E. Guściora-Szeloch, Żydzi i ich rola w dziejach Polski w pracach Szymona Askenazego, w: Wielokulturowe środowisko historyczne Lwowa w XIX i XX w., t. 1, pod red. J. Maternickiego, Rzeszów 2004, s. 253-263; R. Szczerbakiewicz, "Sprytny dostawca optymizmu narodowego"(?). Ostatnie lata Szymona Askenazego na uboczu historii, Polski i Europy, w: Kwestia żydowska w XIX wieku. Spory o tożsamość Polaków, pod red. G. Borkowskiej i M. Rudkowskiej, Warszawa 2004, s. 331-342; T. Wyrwa, Askenazy, jego szkota $i$ apologia patriotyczno-zbrojnego czynu, w: T. Wyrwa, Postannictwo historii czasu pogardy $i$ zakłamania, Lublin 2004, s. 55-72; J. Maternicki, Szkoła Szymona Askenazego, "Annales Academiae Paedagogicae Cracoviensis. Studia ad Institutionem et Educationem Pertinentia" 2005, nr 1, s. 96-109; J. Maternicki, Szymon Askenazy 1867-1935, w: Złota księga historiografii lwowskiej XIX i XX wieku, pod red. J. Maternickiego przy współpracy L. Zaszkilniaka, Rzeszów 2007, s. 321-342; Ł. Kempiński, Szymon Askenazy: historyk, dydaktyk, optymista mimo przeciwieństw, „Studia Pelplińskie" 2008, t. 39, s. 167-183; W. Turant, Askenazy i stan odrzucenia, „Śląsk” 2008, r. 14, nr 5, s. 56-57; J. Maternicki, Historyk i historia. Szymon Askenazy (1865-1935), w: J. Maternicki, Historia i życie narodu. Poglądy i postawy historyków polskich XIX i XX w., Rzeszów 2009, s. 375-403; P. Wandycz, Szymon Askenazy a polityka historyczna, „Polski Przegląd Dyplomatyczny” 2010, nr 4, s. 27-34; K. Lewandowska, Uniwersytet Jana Kazimierza we Lwowie: wybrane sylwetki uczonych
} 
szym zakresie zajmowano się do tej pory działalnością polityczną Askenazego, co stanowi niewątpliwie największą lukę badawczą związaną z tą postacią. Warto przypomnieć, że Askenazy doczekał się dość wcześnie, bo już w 1958 r., swojej biografii naukowej pióra Józefa Dutkiewicza, ale jest ona obecnie mocno przestarzała i niepełna ${ }^{2}$. Niedostatków w wiedzy o Askenazym nie uzupełniła kolejna książka jemu poświęcona, autorstwa Marcina Nurowskiego, choćby z racji jej popularnonaukowego czy wręcz przyczynkarskiego charakteru ${ }^{3}$. Bardzo przydatna dla dalszych studiów nad Askenazym okazała się natomiast niedawno wydana praca Marioli Hoszowskiej, dotycząca nie tylko samego historyka, ale także jego korespondencji i przyjaźni z Ludwikiem Finklem ${ }^{4}$. Na uwagę zasługuje zwłaszcza druga część książki Hoszowskiej, zawierająca 93 listy Askenazego do Finkla z lat 1897-1926. Listy te bowiem, $\mathrm{w}$ powiązaniu $\mathrm{z}$ komentarzem autorki zamieszczonym we wstępie książki, pozwalają zorientować się w rozproszonej po różnych archiwach spuściźnie Askenazego, znajdującej się najczęściej w zbiorach innych historyków5 ${ }^{5}$. Spuścizna ta, dzięki staraniom wielu badaczy, staje się coraz bardziej kompletna i bogatsza niż początkowo sądzono. $W$ jej opisie brakuje jednak ciągle uwzględnienia czternastu listów Askenazego do Adama Skałkowskiego z lat 1901-1913 oraz dwóch kopii listów Skałkowskiego do profesora z lat 1900 i 1904, przechowywanych w Bibliotece Uniwersyteckiej w Poznaniu 6 . Nie jest to wprawdzie duży zbiór listów, ale rzuca on pewne światło na relacje mistrzuczeń, jakie zachodziły między Askenazym a Skałkowskim. Sporządzenie w miarę wyczerpującej listy zachowanych źródeł tyczących się Askenazego przyczyni się w znacznej mierze do napisania w przyszłości nowej, gruntownej monografii o tym znakomitym historyku.

Niniejszy artykuł na ma celu przybliżenie losów i poglądów Askenazego oraz ukazanie wartości jego dokonań na niwie historycznej. Powinien on również odpowiedzieć na trzy zasadnicze pytania: Jakie czynniki ukształtowały postawę naukową Askenazego? Czy uległ on wpływom epoki, w której przyszło mu żyć? I jaką rolę odegrał w ówczesnym środowisku historycznym?

Data urodzenia Askenazego była przez długi czas w literaturze przedmiotu różnie podawana. Uczniowie historyka wskazywali w większości na rok 1867 , kierując się zapewne datą wyrytą na grobie Askenazego ${ }^{7}$. On sam zresztą

polskich, „Perspectiva” 2011, r. 10, nr 2, s. 148-173; T. Budrewicz, Askenazy: zagadnienie literatury i literackości, „Annales Universitatis Paedagogicae Cracoviensis. Studia Historicolitteraria” 2013, nr 13, s. 127-149.

2 J. Dutkiewicz, Szymon Askenazy i jego szkoła, Warszawa 1958.

${ }^{3}$ M. Nurowski, Szymon Askenazy. Wielki Polak wyznania mojżeszowego, Warszawa 2005.

${ }^{4}$ M. Hoszowska, Szymon Askenazy i jego korespondencja z Ludwikiem Finklem, Rzeszów 2013.

${ }^{5}$ Archiwum samego Askenazego uległo zniszczeniu podczas II wojny światowej.

${ }^{6}$ Biblioteka Uniwersytecka w Poznaniu, Spuścizna Adama Skałkowskiego, sygn. 36 IV, k. $28-45,72-80$.

7 M. Kukiel, Szymon Askenazy, „Przegląd Współczesny” 1935, t. 54, nr 161, s. 312. 
podawał ten rok jako datę swojego urodzenia. Mimo to w szkicach o nim wymienia się także rok 1866 lub 1865. Tym dość znaczącym rozbieżnościom położył kres Andrzej Śródka, publikując w 1979 r. krótki artykuł pt. W sprawie daty urodzenia profesora Szymona Askenazego. Okazało się, że autor dotarł do dokumentu - duplikatu Akt Cywilnych Wyznań Niechrześcijańskich Urodzonych, Zaślubionych i Zmarłych w Okręgu Bożniczym Miasta Zawichosta, który dowodzi ponad wszelką wątpliwość, że Askenazy przyszedł na świat, dokładnie 23 grudnia 1865 r. ${ }^{8}$ Wszyscy biografowie historyka od początku byli natomiast zgodni co do tego, że miało to miejsce w Zawichoście, niewielkim miasteczku koło Sandomierza. Pewny jest też fakt, że historyk pochodził ze starej, tradycyjnej rodziny żydowskiej, w której nie brakowało znanych i cenionych postaci. O najstarszym przodku Askenazego wiemy, że żył w XVI w. i zajmował się medycyną oraz dyplomacją. Przez kilka lat był lekarzem przybocznym króla Zygmunta Augusta. Ta wielowiekowa rodzina może się także poszczycić wybitnymi rabinami we Lwowie, Lublinie i Zawichoście. Dość obszerną i ciekawą charakterystykę protoplastów prof. Askenazego opisał jego uczeń Włodzimierz Dzwonkowski ${ }^{9}$. Mimo tak bogatej, ortodoksyjnej tradycji rodzinnej, w domu rodziców historyka - Reginy i Wolfa Askenazych - panował duch polski. On to pewnie sprawił, że „patriotyzm namiętny najstarszego syna wybuchł w nim jak gejzer"10. Pierwsze tego przejawy, może jeszcze nie do końca świadome, uwidoczniły się, gdy uczony skończył trzynaście lat i obchodził uroczystość bar micwy. Wtedy „młody Szymon, długonosy i chudy jak szpagat"11, zachwycił gości, recytując Koncert Jankiela z Pana Tadeusza. Miał ten popis powtórzyć jeszcze przy swoich pierwszych zaręczynach, które zresztą wkrótce zostały zerwane. W wieku dojrzałym, kiedy rozwinął swoją działalność naukową, patriotyzm i przywiązanie do Polski nie tylko stały się mottem jego twórczości, ale wręcz jej motywem przewodnim, jej celem.

Wracając do rodziny historyka, o której w gruncie rzeczy niewiele wiadomo, warto odnotować jeszcze kilka danych. Ojciec Askenazego - kupiec leśny, był człowiekiem "ogólnie poważanym, który między innymi pisywał, czy też inspirował artykuły ze swej dziedziny do »Encyklopedii Rolniczej «"12. Matka zaś Regina cieszyła się dużym szacunkiem i oddaniem swego pierworodnego syna - Szymona. Jej fotografia, obok zdjęć żony i córki, towarzyszyła mu przez całe życie.

${ }^{8}$ A. Śródka, W sprawie daty urodzenia prof. Szymona Askenazego, „Kwartalnik Historyczny” 1979 , r. 86, nr 2, s. 574-575.

${ }^{9}$ W. Dzwonkowski, Szymon Askenazy, „Droga” 1936, t. 15, nr 2-3, s. 132-133. Zob. też: M. Bucior, Z genealogii Szymona Askenazego, s. 91-101.

${ }^{10}$ H. Mortkowicz-Olczakowa, Wspomnienie o Szymonie Askenazym (w 100-rocznice urodzin), „Twórczość” 1967, r. 23, nr 12, s. 82.

11 Tamże, s. 81.

12 W. Dzwonkowski, dz. cyt., s. 133-134. 
Państwo Askenazy mieli oprócz Szymona jeszcze trójkę dzieci: Annę, Rozalię i Henryka. O ich losach wiemy tylko tyle, że obie siostry wyszły za mąż: Anna w Charkowie, a Rozalia w Antwerpii. Najmłodszy zaś z rodzeństwa brat Henryk jako młodzieniec popełnił samobójstwo. Informacje te podaje Hanna Mortkowicz-Olczakowa, której dziadkowie, a później rodzice, znali i przyjaźnili się z rodziną Askenazych ${ }^{13}$.

Edukację młody Szymon rozpoczął, uczęszczając do II Gimnazjum Klasycznego w Warszawie, które ukończył ze złotym medalem w 1883 r., mając osiemnaście lat ${ }^{14}$. Początkowe wykształcenie Askenazego nie wskazywało wcale na późniejsze jego osiągnięcia w dziedzinie historii. Jeszcze bowiem w 1883 r. podjął studia na Uniwersytecie Warszawskim na Wydziale Prawa, spełniając $w$ ten sposób bardziej marzenie ojca niż swoje. Ten czteroletni okres w życiu młodego uczonego skrupulatnie opracował Janusz Woliński, omawiając cały program studiów, które odbywał Askenazy, wymieniając profesorów, z jakimi się stykał, i wreszcie oceny, które uzyskał ${ }^{15}$. Nie pominął Woliński także w swoim artykule rozprawy Askenazego pt. Polityka encyklopedystów, na podstawie której otrzymał on tytuł kandydata nauk. Mimo bardzo dobrej oceny i rekomendowaniu tej pracy do druku w „Wiadomościach Uniwersyteckich" jako wyróżniającej się wartościami naukowymi, ukazał się jedynie jej fragment pt. Mably (1709-1785) na łamach „Ateneum”. Stało się tak dlatego, że wyraźnie przeciwstawił się Askenazemu profesor statystyki Grzegorz Simonienko.

Po ukończonych studiach odbył Askenazy w Warszawie dwuletnią praktykę sądową, po czym uległ namowom Adolfa Pawińskiego i wyjechał do Getyngi. Tam dopiero studia historyczne pozwoliły mu rozwinąć od dawna zakorzenione zainteresowania. Wiedza i umiejętności, jakie zdobył Askenazy w Getyndze, „nazwanej w XIX w. Mekką historyków europejskich”16, rzutowały poważnie na jego dalszą działalność naukową. Na pewno było to wynikiem podjętej tam przez niego intensywnej pracy, którą tak wspominał później jego uczeń Janusz Iwaszkiewicz: „Pokazywał mi kiedyś swe notatki z pobytu w Getyndze. Obok dzieł historycznych, których przerobił wówczas ogromną ilość, interesowała go filozofia, pisma ojców kościoła, nauki społeczne, historia literatury, nauki ścisłe, a zwłaszcza matematyka wyższa, którą do końca życia z zamiłowaniem studiował. Skwapliwie notował wszystko, co dotyczyło Polski i jej spraw. Notatki te pozostały w znacznej części niezużytkowane, widziałem między innymi bardzo obszerne notatki, dotyczące

${ }^{13}$ H. Mortkiewicz-Olczakowa, dz. cyt., s. 82, 84 .

14 J. Woliński, Warszawskie lata uniwersyteckie Szymona Askenazego 1883-1887, „Rocznik Warszawski" 1971, t. 10, s. 145.

15 Tamże, s. 143-148.

${ }^{16}$ J. Serczyk, Przewodnik niosacy otuche, „WTK Tygodnik Katolicki” 1978, r. 27, nr 10, s. 9. 
wszelkich wzmianek i artykułów o Mickiewiczu we współczesnym piśmiennictwie francuskim"17.

Innym, równie istotnym czynnikiem pobudzającym, a zarazem wzmacniającym pasje historyczne Askenazego była niewątpliwie praca pod kierunkiem prof. Maxa Lehmanna. W historiografii niemieckiej Lehmann (1845-1929) rychło pozyskał sobie sławę solidnego i dobrze zapowiadającego się badacza. Nic więc dziwnego, że zainteresowali się nim czołowi niemieccy historycy, w szczególności zaś Heinrich Sybel i Heinrich Treitschke. Oni umożliwili Lehmannowi szybkie rozwinięcie kariery, powierzając mu redakcję „Historische Zeitschrift” oraz wprowadzając go do Zarządu Tajnego Archiwum Pruskiego. I pewnie nic nie zakłóciłoby Lehmannowi zdobywania zaszczytów, gdyby nie jego przekonania i zasady tak różne od obowiązujących wśród starszych kolegów. Trzeba tu bowiem zaznaczyć, że Sybel i Treitschke, będąc gorącymi orędownikami Prus, naginali często swoje pisarstwo do potrzeb państwa. Tymczasem Lehmann nie zamierzał stosować tego procederu i bardziej krytycznie spoglądał na historię. Dosyć ostro ocenił nawet kilka czołowych postaci w dziejach Prus. Najpierw w życiorysie Gerharda von Scharnhorsta obnażył trwożliwość i obłudę Fryderyka Wilhelma III, a później skrytykował Fryderyka Wielkiego jako agresora i inicjatora wojny siedmioletniej ${ }^{18}$. Odważne poglądy Lehmanna bardzo odpowiadały młodemu Askenazemu. Szczególnie cenił on mistrza za przychylny stosunek do Polaków. Generalnie „Askenazy często oceniał badaczy zagranicznych przez pryzmat ich poglądu na sprawy polskie"19.

Fascynacja profesorem z Getyngi i jego pisarstwem sprawiła, że kształtujący się dopiero historyk polski przejął od niego niektóre koncepcje. Podobnie np. jak Lehmann, twierdził, „że dzieje ludzkości są tylko historią bohaterów i górnych postaci, a historia to opowiadanie o indywiduach" ${ }^{20}$. Askenazy zdawał się w pełni wyznawać tę teorię. Widać to zwłaszcza w biografistyce, którą się zajmował, i roli, jaką przypisywał jednostce w procesie dziejowym. Dobitnym tego wyrazem są rozprawy Ksiażę Józef Poniatowski i Łukasiński oraz szereg artykułów poświęconych m.in. Tadeuszowi Kościuszce, Adamowi Czartoryskiemu, Ignacemu Potockiemu oraz Tadeuszowi Korzonowi. Wpływ Lehmanna na Askenazego widać także w innym miejscu, np. negatywne nastawienie Askenazego do wywodów Karola Lamprechta o istocie socjalno-psychologicznych czynników w historii ma zapewne podłoże w konflikcie, jaki zarysował się między Lamprechtem a Lehmannem ${ }^{21}$.

17 J. Iwaszkiewicz, Szymon Askenazy, „Ateneum Wileńskie” 1936, t. 11, s. 894.

18 S. Askenazy, Szkice i portrety, Warszawa 1937, s. 341.

${ }^{19}$ D. Łukasiewicz, Adam M. Skałkowski (1877-1951). Karta z dziejów historiografii niepodległościowej, „Studia i Materiały do Dziejów Wielkopolski i Pomorza” 1990, t. 18, z. 1, s. 185.

${ }^{20} \mathrm{~J}$. Maternicki, Historiografia i kultura historyczna. Studia i szkice, Warszawa 1990, s. 462.

21 Tamże, s. 416-417. 
Pokrewieństwo myśli i wzajemny szacunek, jakie wystąpiły w relacjach Askenazy-Lehmann, sprawiły, że obu historyków połączyła na lata zażyła przyjaźń. Świadczy o tym nie tylko utrzymywana przez nich korespondencja, ale także fakt, że na seminarium profesora z Getyngi Askenazy wysłał swojego ucznia - Adama Skałkowskiego ${ }^{22}$. Śmierć Lehmanna uczcił Askenazy, poświęcając mu obszerny szkic zatytułowany Wspomnienie o prawym historyku, który ukazał się w „Kurierze Warszawskim” w 1933 r. ${ }^{23}$

Wracając do edukacji Askenazego, należy dodać, że studia w Getyndze ukończył w 1893 r. uzyskaniem doktoratu na podstawie rozprawy Die letzte polnische Konigswahl, ogłoszonej drukiem w $1894 \mathrm{r}$. W tym samym roku ukazały się także Studia historyczno-krytyczne - pierwsza książka młodego historyka w języku polskim, która już po trzech latach doczekała się drugiego wydania (Warszawa 1897). Treść tych studiów nie zdradzała wcale wielkiego entuzjazmu dla nauki niemieckiej. Jedyny szkic o historyku niemieckim Leopoldzie Ranke ma wydźwięk raczej krytyczny. Nie należy z tego jednak od razu wnioskować, że polski adept historii negował osiągnięcia Rankego. Wręcz przeciwnie, pisząc o nim artykuł, dał raczej wyraz swego nim zainteresowania. I choć nie podzielał wszystkich poglądów niemieckiego historyka, to doceniał jego metodę naukową, a nawet wzorował się na niej²4.

Pomimo to wydaje się, że Askenazy znacznie większą sympatią darzył myślicieli francuskich niż niemieckich. Świadczą o tym chociażby pozostałe rozprawy Studiów historyczno-krytycznych, które w większości dotyczą francuskich filozofów doby oświecenia (szkice: Mably, Polityka encyklopedystów, Paryż przed stu laty, Taine). Szczególną uwagę warto zwrócić na szkic ostatni. Hippolyte Taine (1828-1893) bowiem jako filozof i historyk, estetyk i teoretyk kultury sformułował swoistą koncepcję dziejów ludzkich, które interpretował jako rezultat wpływu klimatu, rasy i środowiska. Oddziaływanie jego poglądów było bardzo szerokie i przyczyniło się m.in. do powstania naturalistycznej szkoły w literaturze. W historiografii polskiej pod urokiem Taine'a znalazł się przede wszystkim Askenazy, który zawdzięczał mu „najwięcej przyjemności i korzyści" 25 , chociaż nie zgadzał się z nim pod wieloma względami. Zwłaszcza zaś „,szydził z zarysowanego przez francuskiego uczonego psychologicznego obrazu rewolucyjnej Francji, kpił też z charakterystyki Napoleona, który pod względem »rasowym « miał być wyposażony w "górującą cechę samolubstwa«, oczywiście nie jako Francuz, lecz jako potomek Dantego i Michała Anioła"26.

${ }^{22}$ D. Łukasiewicz, dz. cyt., s. 184-185.

23 S. Askenazy, Wspomnienie o prawym historyku - Max Lehmann, „,Kurier Warszawski” 1933, nr 232 (23 sierpnia), s. 4-6.

24 J. Willaume, Epoka nowożytna w dziejopisarstwie polskim i powszechnym, Lublin 1979, s. 35.

25 S. Askenazy, Taine, w: S. Askenazy, Studia historyczno-krytyczne, Warszawa 1894, s. 137.

26 A. Wierzbicki, Spory o polska duszę, Warszawa 1993, s. 207. 
Obok Taine'a nieco młodszym historykiem francuskim, który zafascynował Askenazego, był Albert Sorel (1842-1906). Askenazy uważał go wręcz za swój ideał. Pisał o nim: „Był wielkim historykiem w potrójnym tego słowa znaczeniu: naukowym, obywatelskim i pisarskim. Wielki uczony nie dyletant, wielki pisarz nie rzemieślnik, nie pedant, wielki obywatel pozbawiony przecież jakichś tendencji a priori. Sorel to prawdziwy historyk, przemawiający nie do wąskiego kręgu specjalistów, lecz do ogółu czytającego w kraju. Daleki od działaczy politycznych piszących na tematy historyczne, których czytać niezdrowo, daleki od felietonistów, których czytać nie warto, odbiegający daleko od erudytów zawodowców, których czytać zgoła niepodobna" 27 . Takie określenie Sorela jako historyka właściwie w dużej mierze pasuje też do Askenazego. Wynika to pewnie z tego, że identyczne cele stawiał on przed sobą i tak widział własne powołanie w zawodzie historyka. W swojej twórczości próbował przez wszystkie lata zespolić wspomniane wyżej trzy czynniki: naukowy, obywatelski i pisarski.

Element naukowy w twórczości Askenazego przejawia się niewątpliwie w jego doskonałej znajomości źródeł, rozległej wiedzy i szerokim oczytaniu, przy czym trzeba podkreślić tu fakt, że znakomicie orientował się nie tylko w dziejopisarstwie polskim, ale także zachodnim. Nieobce mu więc były wszystkie nowinki metodologiczne, jakie pojawiały się w nauce zagranicznej.

Również czynnik obywatelski jest doskonale widoczny u Askenazego. Przy pisaniu bowiem każdego dzieła przyświecała mu zawsze jedna myśl służenia narodowi i krzewienia w nim optymizmu. W jednej z rozmów z krytykiem literackim Jerzym Stempowskim Askenazy miał wyznać, że „historię pisał, aby naród, młodzież przede wszystkim, przygotować do nowej walki o niepodległość" ${ }^{28}$. Można tutaj stwierdzić, że w przypadku twórczości historyka nauka ściśle splatała się z ówczesnym życiem politycznym.

Wreszcie element pisarski u Askenazego, często różnie oceniany w literaturze przedmiotu, to głównie dbałość o formę, styl i cechy zewnętrzne dzieła. Do nich szczególnie historyk przykładał dużą wagę, ponieważ dążył zawsze do tego, by dzieła jego były czytane i rozumiane przez najszerszy krąg odbiorców. Wzorował się zresztą w tym względzie na najpoczytniejszych pisarzach brytyjskich (Thomas Macaulay, Thomas Carlyle) i francuskich (Hippolyte Taine, Albert Sorel). To właśnie od Sorela przejął wiele cech zewnętrznych związanych z pisaniem, np. troskę o styl czy oryginalność sądu. Generalnie Sorel wywarł na Askenazym duże wrażenie. Nie tylko bowiem łączyła ich wspólna wizja historyka, ale także podobne zapatrywania na działalność Napoleona i rewolucję francuską. Na pewno też Sorel zdołał zaimponować Askenazemu doskonałą znajomością spraw polskich.

\footnotetext{
27 J. Dutkiewicz, dz. cyt., s. 30.

${ }^{28}$ Historycy warszawscy ostatnich dwóch stuleci, pod red. A. Gieysztora, J. Maternickiego, H. Samsonowicza, Warszawa 1986, s. 196.
} 
To sprawiło zapewne, że wpływ nauki francuskiej i brytyjskiej na polskiego historyka był ogromny i znaczący. Trafne więc wydaje się tutaj stwierdzenie Pawła Szczerby, że „[...] Askenazy, lubo wykształcony na historiografii Niemiec, niczym nie przypomina pedantów i molów książkowych tamtejszych. Jak żaden z młodszych naszych pisarzy, posiada dar żywego opowiadania i barwnego portretowania ludzi. Pomaga mu w tym szerokie oczytanie literackie, niemniej przejęty od Francuzów kunszt malarstwa miniaturowe$\mathrm{go}^{\prime \prime 2}$.

Z takimi umiejętnościami wracał Askenazy z Getyngi do Warszawy. U progu swojej kariery naukowej dysponował zapewne odpowiednią wiedzą i talentem pisarskim, by uprawiać zawód historyka. Tymczasem na ziemiach polskich końca XIX w. nie była to wcale łatwa profesja. Brak państwa polskiego oraz represyjna polityka zaborców, zwłaszcza po upadku powstania styczniowego, skutecznie utrudniały funkcjonowanie i rozwój rodzimej nauki. Szczególnie dotkliwie odczuli to wówczas m.in. historycy polscy. Zajmował się nimi jako grupą zawodową Ryszard Przelaskowski, który tak określił ich ówczesne położenie: „Mała ilość katedr uniwersyteckich i stanowisk $\mathrm{w}$ bibliotekach $\mathrm{i}$ archiwach umożliwiła zatrudnienie $\mathrm{w}$ nich jedynie ograniczonej ilości uczonych. Stąd też dla wielu historyków ich praca badawcza nie miała charakteru zarobkowego. Często są oni zmuszeni podejmować się prac zawodowych, nie zawsze mających coś wspólnego z ich zainteresowaniami poznawczymi. Sporo też osób opiera swój byt na różnych własnych źródłach dochodu. Wszystko to wpływa w sposób hamujący na rozwój historiografii i decyduje w dużym stopniu o profilu społecznym historyków"30.

Askenazy należał akurat do tej szczęśliwej grupy naukowców, którzy mogli sami finansować swoje pasje i zamiłowania. Gdyby nie jego majątek, utrzymywanie się samemu przez osiem lat pracy na Uniwersytecie Lwowskim byłoby niemożliwe. Nawet w następnych latach, kiedy wypłacano mu 300 guldenów wynagrodzenia, a w 1906-1907 wyjątkowo 1500, nie wystarczyłoby to na życie, jakie zwykł prowadzić. Opłacał bowiem dwa mieszkania i dwie biblioteki, podróżując nieustannie między Lwowem a Warszawą. Ponadto wyjeżdżał często do archiwów europejskich ${ }^{31}$.

Sytuacja materialna Askenazego, ugruntowana dodatkowo małżeństwem z Fenicją Tikociner - córką bogatego fabrykanta łódzkiego, nie stanowiła więc przeszkody w realizacji jego planów zawodowych. Te zaś wyraźnie zarysowały się dzięki styczności z wybitnymi przedstawicielami nauki i inteligencji warszawskiej. To właśnie w Warszawie, z którą Askenazy był mocno związany, poznał polskich mistrzów swojego fachu. Zetknięcie się z nimi, dostrze-

29 P. Szczerba, Prace profesora Askenazego, „Krytyka” 1903, t. 1, s. 142-143.

${ }^{30}$ R. Przelaskowski, Historiografia polska w dobie pozytywizmu (1865-1900). Kompendium dokumentacyjne, Warszawa 1968, s. 44.

31 W. Dzwonkowski, dz. cyt., s. 141. 
żenie wartości ich poglądów i prac miało równie ważne, a może nawet ważniejsze znaczenie dla Askenazego niż młodzieńczy jego zachwyt pisarzami francuskimi. Pracował przecież Askenazy na gruncie polskim, w konkretnych, trudnych warunkach, gdzie sytuacja instytucjonalna historii jako nauki w każdym z zaborów przedstawiała się odmiennie.

Warszawa akurat pod względem naukowym była ośrodkiem prężnym i znaczącym. Historię wykładano tam najpierw w Szkole Głównej przez siedem lat jej działalności (1862-1869), a później w Cesarskim Uniwersytecie Warszawskim. Dlatego też ze Szkołą Główną związani byli bezpośrednio lub pośrednio prawie wszyscy historycy warszawscy działający w latach siedemdziesiątych i osiemdziesiątych XIX w. Jednym z wykładowców tej szkoły, krótko co prawda, bo tylko półtora roku, był Adolf Pawiński, ten sam, który namówił Askenazego na wyjazd do Getyngi. Publikacje i prelekcje Pawińskiego reprezentowały szczególnie wysoki poziom w zakresie teorii i metodologii historii. Nic więc dziwnego, że zwykle zalicza się go do czołowych przedstawicieli warszawskiego środowiska historycznego. Obok niego równie zaszczytne miejsce zajmowali wówczas: Aleksander Rembowski, kontynuator badań Pawińskiego nad ustrojem Polski, oraz Aleksander Jabłonowski i Władysław Smoleński.

Zdecydowanym jednak liderem wśród historyków warszawskich okazał się Tadeusz Korzon. On to swoją pracą pt. Wewnętrzne dzieje Polski za Stanisława Augusta, której tom pierwszy ukazał się w 1882 r., a drugi w 1886, zapoczątkował tzw. szkołę warszawską. Cechą charakterystyczną tej szkoły był kształtujący się stopniowo optymistyczny pogląd na przeszłość Polski. W Warszawie i w całym Królestwie, które najbardziej ucierpiało po klęsce powstania styczniowego, pozytywna ocena sił tkwiących w polskim narodzie, szczególnie w okresie przedrozbiorowym, przywracała zachwianą wartość własnej narodowości. Hasła i poglądy głoszone przez przedstawicieli szkoły warszawskiej, podkreślające, że upadku państwa nie można utożsamiać z upadkiem narodu, przyczyniły się rychło do odrodzenia polskiej myśli niepodległościowej.

W tych warunkach Askenazy, obcując przez dwa lata z warszawskimi mistrzami słowa i nauki, uformował ostatecznie swoją postawę historyka. Pod tym względem nieocenioną rolę odegrała dla niego ciepła i długoletnia przyjaźń z Tadeuszem Korzonem i Stanisławem Łaguną. Ten ostatni, choć nie był historykiem, lecz prawnikiem, zachwycił Askenazego „wysokim intelektem, głęboką znajomością nie tylko przeszłości własnego kraju, ale w równej mierze kultury i literatury francuskiej w jej najświetniejszym okresie wieku XVII i XVIII, jak współczesnych prądów umysłowych. Szczery podziw budziła w początkującym historyku umiejętność heurezy i krytyki źródeł S. Łaguny"32. Nie mniejszy wpływ na Askenazego wywarł także Korzon.

${ }^{32} \mathrm{H}$. Barycz, Na przełomie dwóch stuleci. Z dziejów polskiej humanistyki w dobie Młodej Polski, Wrocław 1977, s. 252. 
Swoim pisarstwem inspirował on młodego Askenazego, stanowiąc dla niego wzór historyka i patrioty. To w domu Korzonów młody historyk spotykał się nieustannie z tradycją i atmosferą polską, goszcząc tam często na czwartkowych, potem zaś środowych zebraniach. Sam Korzon podobno mało kogo cenił naprawdę spośród historyków piszących u schyłku XIX w. - z wyjątkiem właśnie Askenazego, którego uznawał nawet za swego kontynuatora. Nic więc dziwnego, że starał się zapewnić mu korzystną pozycję naukową, która pozwoliłaby na swobodne rozwijanie jego zainteresowań i uzdolnień. Najpierw więc zaprosił go do współpracy w Wielkiej Encyklopedii Ilustrowanej oraz ułatwił mu dostęp do wielu czasopism warszawskich. Następnie przy sprzyjających okolicznościach pragnął wyjednać dla niego miejsce na Uniwersytecie Krakowskim. Zabiegi Korzona podjęte w tym kierunku były jak najbardziej uzasadnione nie tylko z uwagi na wiedzę i talent Askenazego, ale także ze względu na aktualne wówczas dążenia do odnowienia uniwersyteckiego nauczania w obydwóch galicyjskich uczelniach. Odnowienie to miało polegać głównie na unowocześnieniu metodologicznym, głębszym ujęciu procesów dziejowych, większym zainteresowaniu historią społeczną i gospodarczą, a także historią oświaty i kultury. Reforma uczelni galicyjskich miała też na celu wprowadzenie nauki historii najnowszej, a więc „wyjście poza oficjalną, nieprzekraczalną dotąd granicę czasów rewolucji francuskiej i epoki napoleońskiej w dziedzinie historii powszechnej, zaś poza epokę rozbiorów na polu historii ojczystej" 33 .

Biorąc pod uwagę powyższe postulaty rozwoju uniwersytetów oraz zainteresowania Askenazego historią najnowszą, trudno wyobrazić sobie lepszego kandydata do krakowskiego grona wykładowców. Będąc o tym głęboko przekonany, Korzon zwrócił się w 1896 r. do ówczesnego rektora Uniwersytetu Jagiellońskiego Stanisława Smolki z zapytaniem o warunki i możliwości habilitacji gruntownie wykształconego i uzdolnionego Askenazego. Odpowiedź Smolki, choć grzeczna i wyważona, uznająca wartość prac młodego historyka, była jednak odmowna. U podstaw takiej jego decyzji legły głównie dwa powody.

Po pierwsze, Smolka twierdził oficjalnie, że opuszczanie Warszawy i Poznania przez prawdziwych uczonych jest dla tych miast pod względem naukowym wysoce niekorzystne. Po drugie zaś, otwarcie przyznał: „, co do mnie to nie jestem antysemitą, ale się też nie poczuwam do filosemityzmu; znając jednak grunt muszę wyrazić przekonanie, że Żyd nie dobiłby się dzisiaj u nas z łatwością katedry na wydziale filozoficznym, który już dwóch Żydów $\mathrm{w}$ gronie swym posiada" ${ }^{\prime 34}$. Ten argument, całkowicie pozanaukowy, był dla Smolki wystarczającą przeszkodą uniemożliwiającą przyjęcie Askenazego na

${ }^{33}$ H. Barycz, Zamierzona habilitacja Szymona Askenazego, w: H. Barycz, Alma Mater Jagiellonica. Studia i szkice z przeszłości Uniwersytetu Krakowskiego, Kraków 1958, s. 214-215.

${ }^{34}$ Tamże, s. 218. 
uczelnię. Dodatkowym wydarzeniem, które zaważyło ostatecznie na odrzuceniu przez Smolkę wniosku Korzona w sprawie Askenazego, były protesty studentów, do jakich doszło w tym czasie w Krakowie przeciw sposobom nauczania historii. Protesty te miał inspirować Korzon, co odbiło się niekorzystnie na jego relacjach ze Smolką. Dla uzupełnienia warto tutaj wspomnieć, że protest studentów krakowskich nie był przypadkowy, lecz stanowił element sporu, który w końcu XIX w. toczył się między historyczną szkołą warszawską a szkołą krakowską. Askenazy, rozpoczynając swoją działalność naukową w Królestwie Polskim, był świadkiem i obserwatorem tych waśni.

Szkoła krakowska, w przeciwieństwie do warszawskiej, reprezentowała pesymistyczny pogląd na przyszłość Polski. W wadach narodowych i anarchii wewnętrznej widzieli jej przedstawiciele genezę rozbiorów. Samo ukształtowanie się szkoły krakowskiej w II połowie lat sześćdziesiątych XIX w. nastąpiło znacznie wcześniej niż warszawskiej. Za założyciela nurtu pesymistycznego w historii uznaje się Waleriana Kalinkę, który swoje poglądy zawarł w dziele pt. Ostatnie lata panowania Stanistawa Augusta (1868). Solidarnie wtórował mu pod tym względem Józef Szujski, autor Dziejów Polski (1866), oraz nieco później Michał Bobrzyński, który zasłynął głównie dzięki kontrowersyjnej syntezie pt. Dzieje Polski w zarysie (wyd. I 1879). O ile poglądy głoszone przez szkołę warszawską przyczyniły się do odrodzenia polskiej myśli niepodległościowej, o tyle sądzono często, że szkoła krakowska roli takiej nie odgrywała. Wyrazicielem podobnej opinii był także uczeń Askenazego, Wacław Mejbaum, który utrzymywał, „, iż szkoła krakowska stworzyła ideologię historyczną Polski niewolnej, stojącej i stawianej na gruncie obcej państwowości. Zrodziła się ona po klęsce 1863 r., w okresie rozkładu i zniszczenia narodu, jako historycznej i państwowej kategorii" ${ }^{\prime 35}$. Ten zbyt krytyczny może osąd wychowanka Askenazego świadczy o tym, że odkąd zrodziły się dwie odmienne wizje przeszłości Polski, budziły one żywe dyskusje i polemiki, a podział na zwolenników optymistycznego i pesymistycznego ujmowania dziejów utrzymuje się zapewne do dziś.

Sam Askenazy w swej twórczości naukowej zdecydowanie skłaniał się ku szkole warszawskiej. Znacznie bardziej odpowiadała mu pozytywna ocena przeszłości narodu polskiego. W swoim pisarstwie historycznym poszedł on nawet nieco dalej niż szkoła warszawska. Jako "ostatni romantyk" - jak nazywał go Andrzej Zahorski - Askenazy dostrzegał i omawiał te momenty w historii Polski, które budziły nadzieję i wiarę w siły oraz możliwości narodu. O ile więc w dziedzinie literatury krzepił Polaków Henryk Sienkiewicz, o tyle na polu historii robił to Szymon Askenazy, odnosząc zresztą spore sukcesy. Sławą bowiem i poczytnością swoich dzieł dorównywał w owym czasie Sienkiewiczowi. Mimo tych osiągnięć droga naukowa historyka nie była wcale łatwa. Zwrócił na to szczególną uwagę Henryk Barycz, ukazując postać

35 J. Maternicki, Historia jako dialog, Rzeszów 1996, s. 16. 
Askenazego „wśród przeciwieństw i niepowodzeń życiowych i naukowych”. Tak opisał on kolejny etap życia i starań historyka, którego nie przyjęto do zespołu profesorów krakowskich: „W tym stanie rzeczy, który nie rokował większych nadziei na zapewnienie Askenazemu miejsca w Krakowie, zwrócono uwagę na Lwów. Istnieje pogłoska, trudna do sprawdzenia, że do habilitacji warszawskiego historyka utorował drogę książę Adam Sapieha. Pewne natomiast jest, iż decydującym człowiekiem, który przeprowadził przewód habilitacyjny, otoczył od samego początku żarliwą opieką, trwającą do końca swego życia miłością i przyjaźnią i zaważył w ogóle na dalszej przyszłości Askenazego, był profesor historii polskiej w tymże uniwersytecie - Tadeusz Wojciechowski, historyk - dysydent, uczony niezależny, dużej odwagi cywilnej, który z tych powodów musiał opuścić Kraków" ${ }^{\prime 36}$.

Nieco dalej Barycz wspomina o przyjaźni, jaka łączyła we Lwowie Szymona Askenazego z Karolem Lanckorońskim, właścicielem Rozdołów, historykiem i mecenasem sztuki. Stawia nawet związaną z tym pewną hipotezę, pisząc: „[...] niewyłączone, że Lanckoroński współdziałał w osadzeniu autora Ostatniego bezkrólewia na Uniwersytecie Lwowskim (a nie »czerwony książę « Adam Sapieha, jak to czasem się powtarza)" ${ }^{37}$. Sprawa ta pozostaje jednak do końca nierozstrzygnięta.

Wiadomo natomiast na pewno, że Askenazy habilitował się w 1897 r. na Wydziale Filozoficznym Uniwersytetu Lwowskiego z historii nowożytnej na podstawie pracy pt. Przymierze polsko-pruskie, uważanej przez niektórych badaczy za najważniejsze dzieło historyka. On sam zaś, w ciągu następnych lat działalności na uniwersytecie, znacznie ożywił swoje pisarstwo. Nie bez przyczyny uznaje się właśnie okres lwowski w twórczości naukowej Askenazego za najpłodniejszy i niezwykle dynamiczny. Jego wytrwałe i mozolne badania zaowocowały szybko dziełami, które rozgrzały serca Polaków.

Po Przymierzu polsko-pruskim, które wydano w całości po raz pierwszy w 1900 r., przyszedł czas na biografie dwóch polskich bohaterów: Książe Józef Poniatowski (wyd. I 1904) i Łukasiński (wyd. I 1908), oraz obszerną, niedokonczoną monografię pt. Napoleon a Polska (wyd. I 1918-1919). W tym samym czasie Askenazy napisał także: Dwa stulecia XVIII i XIX (wyd. I 1901), Sto lat Zarządu w Królestwie Polskiem (1800-1900) (wyd. I 1901) oraz Wczasy historyczne (wyd. I 1902) i Rosja-Polska 1815-1830 (wyd. I 1907).

Jak wynika z samych tytułów tych prac, dotyczyły one wszystkie historii najnowszej, dzięki której oddziaływał Askenazy na umysły i uczucia współczesnych mu Polaków. O roli, jaką przypisywał dziejom najnowszym w rozwoju nauki historycznej, świadczy wymownie jego credo naukowe, które ogłosił w 1900 r. na III Zjeździe Historyków Polskich w Krakowie. Zjazd ten odbył się 4-6 czerwca 1900 r. z inspiracji Towarzystwa Historycznego,

\footnotetext{
${ }^{36}$ H. Barycz, Na przełomie dwóch stuleci, s. 256-257.

37 Tamże, s. 259-260.
} 
które chciało w ten sposób uczcić jubileusz Uniwersytetu Jagiellońskiego ${ }^{38}$. Rychło okazało się, że Zjazd ten miał dla nauki polskiej szczególne znaczenie, zwłaszcza w zakresie refleksji teoretycznej i metodologicznej nad historią. Referaty, które wygłosił Askenazy podczas obrad o historii politycznej, poświęcone były epoce saskiej i porozbiorowej. Zwracały one uwagę uczestnikom Zjazdu, w jakim kierunku powinna rozwijać się polska myśl historyczna, jakie obszary dziejów powinni badacze przeanalizować i opracować. Mówił więc Askenazy tak: „Jest czas najwyższy wziąć się nareszcie na całej linii, z całym impetem do pełnej i szczerej roboty naukowej koło dziejów porozbiorowych. Są one u nas i tylko u nas ciągle uważane niemal za współczesność jeszcze jakoby niedojrzałą dla umiejętnych badań; są ciągle ostrożnie omijane, niby czysta, jeszcze jakoby żarząca się polityka. To jest złudzenie [...] Tutaj jest szeroka szczerba pomiędzy nauką a życiem [...], którą potrzeba wypełnić. Potrzeba nieodbicie i niezwłocznie dla dwóch mianowicie naczelnych powodów.

Potrzeba nasamprzód, i to główna, dla oświecenia własnego ogółu. W wyczerpujących, metodycznych, a na wskroś rzeczowych badaniach nad epoką, o której mowa, on powinien odnaleźć nareszcie złożony tam dla niego obfity zasób wielolicznych, tak drogo okupionych, a tym szacowniejszych doświadczeń [...].

Potrzeba, po wtóre, i to także dosyć ważna, dla oświecenia obcych. Europejska wytwórczość naukowa w zakresie dziejów, tzw. najnowszych, tj. odpowiadających porozbiorowym, ostatnimi czasy wzmogła się niesłychanie i wzmaga się coraz bardziej. Na szalę historycznego sądu o tych dziejach Niemcy, Rosjanie, Francuzi rzucają bez przerwy całe łaszty imponujących wydawnictw i opracowań źródłowych największej wagi. My sami tylko nie kładziemy nic, albo prawie nic. Jesteśmy tutaj nie tylko zdystansowani, ale po prostu nieobecni [...]. Skutki takiego stanu rzeczy są oczywiście opłakane [...]. $\mathrm{W}$ nauce, jak i gdzieindziej, trudno wymagać, dzisiejszymi zwłaszcza czasy, sprawiedliwości zaocznej. Zaś dotychczas, przed forum historiografii powszechnej, najżywotniejsze sprawy nowoczesnych dziejów naszych wywoływane i sądzone są zaocznie $[\ldots]^{\prime \prime 39}$.

Takie słowa w ustach młodego jeszcze, bo trzydziestopięcioletniego wówczas Askenazego, brzmiały zapewne poważnie i dostojnie. Były one przejawem jego dużej odwagi cywilnej i niezależności poglądów, które formułował. Reprezentował przecież Askenazy na Zjeździe grupę historyków średniego pokolenia, do którego zaliczyć można także: Wiktora Czermaka (Uniwersytet Jagielloński), Stanisława Estreichera (Uniwersytet Jagielloński), Jana Kochanowskiego (Warszawa), Wilhelma Feldmana (Uniwersytet Jagielloński) i in.

${ }^{38}$ R. Przelaskowski, dz. cyt., s. 174.

${ }^{39}$ Cyt. za B. Pawłowski, Szymon Askenazy, „Kwartalnik Historyczny” 1935, r. 49, s. 548-549 . 
Dziś, z perspektywy czasu, Askenazego uważa się za najwybitniejszego w tym gronie. To pewnie zdecydowało też o tym, że wśród historyków starszych i zasłużonych już na polu nauki, że wymienię tu choćby: Oswalda Balzera (Uniwersytet Lwowski), Michała Bobrzyńskiego (Uniwersytet Jagielloński), Ludwika Finkla (Uniwersytet Lwowski), Wojciecha Kętrzyńskiego (Lwów) czy Tadeusza Wojciechowskiego (Uniwersytet Lwowski), Askenazy swobodnie wykładał swoje tezy i postulaty. Najlepszym tego dowodem jest dalsza treść cytowanego wyżej referatu, w którym jego autor dość ostro skrytykował swego mistrza i przyjaciela Tadeusza Korzona za błędne przedstawienie legionów polskich i Napoleona. Stwierdził bowiem Askenazy w swojej mowie: „Dzieje legionów nie są ani w części dostatecznie znane. Gorzej, bywają fatalnie zapoznawane. I to najnowszymi nawet czasy. Wszak przed czasem bardzo niedawnym badacz pierwszorzędny, pisarz pięknej Kościuszkowskiej monografii, mógł ogłosić legionistów »maniakami «, dźwigającymi »odziedziczoną po przodkach chorobę umysłową«, uznać w nich »najemników « [...], zarzucić im »zdradę stanu«, wskazać »karę główną« jako zasłużoną ich nagrodę. Niezbędną jest rzeczą, w interesie najoczywistszej prawdy i najprostszej słuszności, założyć wyraźny protest przeciw takim zboczeniom historycznego sądu. Jednakowoż, ten protest skierować należy nie tyle przeciw wybitnemu badaczowi, który tutaj ciężko pobłądził, ale którego własne znakomite zdobycze specjalne na innym spoczywają terenie - ile przeciw właściwej historiografii porozbiorowej, która do podobnych błędów daje dopiero powód i pochop przez gorszące zaniedbanie, w swoim zakresie specjalnym, wszelkiej porządnej produkcji wydawniczej i krytycznej" 40 .

Po takich słowach swego wychowanka Korzon poczuł się upokorzony i zraniony. Smutek swój wyrazil, przyznając, że „zarzut ten pochodzi od wysoce uzdolnionego i życzliwego mu osobiście historyka, a brzmi jeszcze dobitniej, niż podobny zarzut dra Rembowskiego, zamieszczony we wstępie do nowej monografii O pułku szwoleżerów" ${ }^{\prime \prime 1}$. Ostatecznie Korzon sam sobie przypisał winę, że nie potrafił przekonać tak życzliwego człowieka, jakim był dla niego Askenazy. Oświadczył też, że niczego ze swojego dzieła nie cofa ani za błąd nie uznaje.

W odpowiedzi Korzonowi Askenazy podkreślił, że zarzut swój traktuje „,jako najwyższy wyraz hołdu, oddanego w ten sposób wyjątkowemu stanowisku Korzona w historiografii nowoczesnej polskiej i jego zasłużonemu wpływowi i powadze, dla której to właśnie jest obowiązkiem nie pomijać jego poglądów, tam, gdzie wydają się błędnymi"42.

40 S. Askenazy, Epoka porozbiorowa 1795-1830, w: Pamiętnik III Zjazdu Historyków Polskich w Krakowie, t. 1, Referaty, Warszawa 1901, s. 6.

${ }^{41}$ Pamiętnik III Zjazdu Historyków Polskich w Krakowie, t. 2, Protokoty, Warszawa 1901, s. $45-47$.

42 Tamże, s. 45-47. 
W takim, bardzo kurtuazyjnym i uprzejmym tonie toczyła się polemika Tadeusza Korzona z Szymonem Askenazym. Różnica poglądów, jaka się wtedy między nimi ujawniła, nie zaprzepaściła podobno ich przyjaźni, której obaj do końca byli wierni.

Askenazy zaś, biorąc udział w tego rodzaju dyskusjach, prowadzonych podczas omawianego Zjazdu, stał się jego czynnym uczestnikiem, który na dodatek zawsze pamiętał o swoim głównym przesłaniu. Dlatego też, przy okazji referatu Bronisława Dembińskiego o Stanie nauki historycznej pod względem metody, wygłoszonego dzień wcześniej niż prelekcje Askenazego, skonkretyzował on już swoje cele. Uważał, że w zakresie dziejów polskich nowożytnych i najnowszych należy „podjąć robotę $\mathrm{w}$ dwóch kierunkach: 1. ściśle naukowym, przez opracowanie monograficzne i wydawnictwo źródeł, za przykładem nadzwyczajnego zasobu odpowiednich publikacji zagranicznych, oraz 2. w kierunku naukowo-popularyzatorskim przez rozumowane edycje najważniejszych aktów [...], np. byłby pożądany tani i przejrzysty zbiór traktatów podziałowych w przekładzie polskim, biegnący od 1772 do 1846 i innych tym podobnych wydawnictw naukowo-popularnych, które miałyby dużą wartość edukacyjną [...]"43.

Tak brzmiał skrót „programu” Askenazego w zakresie badań dziejów najnowszych, który nie tylko historyk konsekwentnie głosił, ale i realizował. Wkrótce okazało się także, że nie był w tych działaniach całkiem osamotniony. Oto bowiem w czasie ostatniego przemówienia Zjazdu jego prezes Michał Bobrzyński, zamykając i podsumowując obrady, stwierdził: „Jeżeli wolno mi z tego miejsca wysunąc pewną konsekwencję, to rzucę tę myśl, jako program następnego Zjazdu. Zdaje mi się, że jest rzeczą Towarzystwa Historycznego i Komisji Historycznej Akademii Umiejętności, aby zszeregowała materiały do historii nowożytnej, aby podzieliła je na grupy i żeby na następnym Zjeździe w jednym referacie przedstawiła projekt, w jakim porządku i co wydawać, licząc się ze środkami i materiałem, którym rozporządza, i z tymi, którzy by się tego podjąć chcieli" ${ }^{44}$.

Taki wniosek Michała Bobrzyńskiego świadczy dobitnie o tym, że starania i namowy Askenazego odniosły niemal natychmiastowy skutek. Rzeczywiście wkrótce w ramach Akademii Umiejętności powołano Komitet do Dziejów Polski Porozbiorowych. Wynikiem jego prężnej działalności był szereg monografii, jak choćby książka Stanisława Smolki o Franciszku Ksawerym Lubeckim oraz wydawnictwo źródłowe Michała Rostworowskiego, zawierające m.in. obszerny Diariusz sejmu 1830 i 1831 r. (1907-1912), a także Protokóty Komisji Rządzacej z r. $1807(1918)^{45}$.

\footnotetext{
43 Tamże, s. 21.

44 Tamże, s. 130-131.

45 K. Tymieniecki, Zarys dziejów historiografii polskiej, Kraków 1948, s. 85.
} 
Bezpośrednim i jednocześnie najznakomitszym rezultatem postulatów Askenazego była zainicjowana przez niego samego seria wydawnicza zatytułowana "Monografie w zakresie dziejów nowożytnych". Autorami poszczególnych tomów monografii, których w latach 1902-1919 ukazało się siedemnaście, byli jego najzdolniejsi uczniowie. Askenazy uważał bowiem, że tego rodzaju przedsięwzięcie naukowe przekracza siły jednego człowieka. Stąd swoimi współpracownikami uczynił uczniów, których zachęcał i dopingował do pracy. Sam zaś gotowe już monografie promował, pisząc do każdej wstęp, zawierający m.in. prezentację młodego autora. Zakres tematyczny promowanych przez Askenazego prac był bardzo szeroki, począwszy od historii politycznej doby napoleońskiej i kongresowej, na dziejach edukacji narodowej i Kościoła kończąc. Bogactwo owych prac wskazuje na to, że inicjatywa Askenazego dotycząca wydawania monografii była trafna i udana.

Nie można tego natomiast powiedzieć o wydawnictwach źródłowych, których dotkliwy brak wykazał Askenazy na Zjeździe. Właściwie jedyną tego rodzaju pracą, w której przygotowaniu sam uczestniczył, były dwa tomy Akt powstania Kościuszki. W dość krytyczny sposób skomentował ten fakt Juliusz Willaume, współczesny historyk, od 1953 r. profesor Uniwersytetu Lubelskiego: „Widocznie krewkiemu temperamentowi Askenazego, nastawionego na ogarnianie szerszych zagadnień, zdobywanie kluczowych pozycji, nie odpowiadała żmudna praca edytorska, wymagająca cierpliwości i systematyczności" ${ }^{46}$.

III Zjazd Historyków Polskich z 1900 r. zaważył znacząco nie tylko na naukowej dziedzinie historii. Odbił się też szerokim echem wśród inteligencji polskiej, szczególnie zaś w gronie publicystów i literatów. Było to w dużej mierze możliwe dzięki opublikowaniu w 1901 r., po niewielkich tylko skreśleniach cenzury, referatów zjazdowych w cytowanym wyżej Pamiętniku. Zwłaszcza ci pisarze, twórcy literatury pięknej, którzy interesowali się epoką porozbiorową, mogli znaleźć tam ciekawe poglądy oraz materiały dotyczące tego okresu. Samo zafascynowanie mistrzów beletrystyki dziejami najnowszymi było już dużym osiągnięciem. O zauroczeniu takim można chyba mówić, zważywszy, że po 1900 r. mnożą się tytuły powieści, których akcja rozgrywa się w niedalekiej przeszłości. Wspomnijmy tu choćby książki Walerego Przyborowskiego pt. Szwoleżer Stach (1900) i Noc styczniowa (1903), Wacława Gąsiorowskiego pt. Huragan (t. 1-3, 1902), Rok 1809 (t. 1-2, 1903), Szwoleżerowie gwardii (t. 1-2, 1910), Księżna Łowicka (1908) i Emilia Plater (1910) oraz Wiktora Gomulickiego pt. Grandmuszkieter (1911) i Bój olbrzymów (1913).

Najbardziej jednak znaczącym utworem w literaturze młodopolskiej, podejmującym temat czasów napoleońskich, były wówczas i są do tej pory Popioły Stefana Żeromskiego. Udziałem Askenazego w genezie tej książki

${ }^{46}$ J. Willaume, dz. cyt., s. 52. 
zajmował się filolog Stanisław Zabierowski. Na podstawie analizy oryginalnych zachowanych brulionów powieści i porównania ich $\mathrm{z}$ wersją drukowaną doszedł on do wniosku, że są one różne, szczególnie we fragmentach dotyczących legionistów. Dowodził także, że zmiany te są odzwierciedleniem znajomości tekstu zjazdowego referatu Askenazego oraz bezpośrednich konsultacji pisarza $\mathrm{z}$ historykiem ${ }^{47}$.

Skoro jesteśmy już przy literaturze, warto jeszcze zwrócić uwagę na fakt, że pod wpływem Askenazego i jego twórczości znaleźli się nieco później, bo w okresie międzywojennym Skamandryci. Grupa ta obejmowała w zasadzie pięciu czołowych poetów: Jana Lechonia, Antoniego Słonimskiego, Jarosława Iwaszkiewicza, Juliana Tuwima i Kazimierza Wierzyńskiego. Co do dwóch pierwszych, wiadomo na pewno, że postać Askenazego jako historyka była im bliska.

Szczególnym uwielbieniem darzył Askenazego Lechoń, wychwalając nie tylko jego inteligencję i wiedzę, ale także niepospolity talent. Sam, będąc znanym literatem i autorem cenionych wierszy, miał podstawę i możliwości ku temu, by profesjonalnie ocenić styl historyka. Jego odczucia wyrażały następujące słowa: „[...] proza Askenazego pięknie robiona, czasem bodaj grzesząca nadmiarem sztuki, w chwilach patosu, wzruszenia sięgała tego piękna, tej prostoty, które zacierają granice między poezją a prozą" ${ }^{\prime 4}$.

Podobnie, bardzo pozytywnie wyrażał się o historyku Słonimski. W swoim Alfabecie wspomnień zapisał: „Askenazemu zawdzięczam sporo pięknych chwil, nieco wiadomości z historii i jedną prawdę, której nie zapominam, że lato najmilej spędzić w Warszawie"49.

Nie zapomniał też Antoni Słonimski, a za nim inni Skamandryci, o Askenazym krótko po odzyskaniu niepodległości, w istotnym momencie jego życia naukowego. $W$ pierwszych bowiem latach odradzającego się państwa polskiego Askenazy podjął starania o katedrę historii na Uniwersytecie Warszawskim. Jednak za sprawą nieprzychylnych czy wręcz wrogich mu, za to dość wpływowych członków Wydziału Historycznego (Bronisława Dembińskiego i Marcelego Handelsmana) odrzucono jego kandydaturę zarówno na Wydziale Historii, jak i Wydziale Prawa. Wtedy z protestem wobec takiej decyzji wystąpili spontanicznie nie tylko studenci, ale także przedstawiciele świata kultury, a wśród nich wszyscy czołowi Skamandryci. Ich apel Przeciwko niedopuszczeniu prof. Askenazego, opublikowany w "Robotniku” 2 marca 1920 r., wzywał władze uczelni: „Chcemy wierzyć, że decyzja Senatu Akademickiego rychłej ulegnie rewizji, że krzywda wyrządzona wielkiemu uczonemu czym prędzej

47 S. Zabierowski, Udział Askenazego i jego szkoty w genezie »Popiołów «, „Pamiętnik Literacki” 1965, r. 56, z. 1, s. 216, 232.

${ }^{48}$ H. Barycz, dz. cyt., s. 245.

49 A. Słonimski, Alfabet wspomnień, Warszawa 1975, s. 11. 
zostanie naprawiona, i że doświadczony głos jego donośnie rozbrzmiewać będzie z katedry młodej wszechnicy warszawskiej" 50 .

Wspominając te wydarzenia z roku 1920, wybiegliśmy nieco w przyszłość. Tymczasem, aby poznać wszystkie szczeble drogi naukowej Askenazego, należy wrócić do roku 1902. Wtedy bowiem, dokładnie 12 lutego 1902 r., otrzymał historyk tytuł profesora nadzwyczajnego. Nominacja ta, podobnie jak i następna, z roku 1907, na profesora zwyczajnego historii nowożytnej, ze szczególnym uwzględnieniem polskiej, nie były dobrowolne, a decyzje o nich nie zapadały szybko i entuzjastycznie. Co było powodem takiego stanu rzeczy, trudno jednoznacznie określić. Z całą pewnością można jedynie stwierdzić, że w przypadku objęcia po Tadeuszu Wojciechowskim Katedry Historii Polskiej w 1906 r., przeciwko Askenazemu zdecydowanie wystąpił Bronisław Dembiński, profesor historii powszechnej we Lwowie. Zarzucał on Askenazemu m.in. brak kwalifikacji na tak ważne stanowisko oraz jego żydowskie pochodzenie. Zresztą obaj historycy już od końca XIX w. pozostawali w ostrym konflikcie, który ujawnił się po raz kolejny właśnie w $1906 \mathrm{r}$. Nie zdołał jednak Dembiński udaremnić nominacji Askenazego, którą z wielkim aplauzem i ożywieniem przyjęli uczniowie historyka. W zatłoczonej sali wykładowej nagrodzono Askenazego oklaskami, dając tym wyraz swojego doń przywiązania. Podobnie też uczczono w 1910 r. mianowanie Askenazego czynnym członkiem Akademii Krakowskiej ${ }^{51}$. Taka reakcja młodzieży na sukcesy profesora wskazuje na popularność i szacunek, jakim go darzono.

Generalnie między licznymi nieprzyjemnościami i trudnościami, z którymi stykał się Askenazy w swojej pracy zawodowej, pewną rekompensatę przynosiła mu działalność dydaktyczna i jej rezultaty. Wykłady prowadził Askenazy na Uniwersytecie Lwowskim od 1898 r. Ich zakres obejmował dzieje polityczne Europy i Polski w XVIII i początkach XIX w. Ze wspomnień słuchaczy tych wykładów wynika, że profesor wygłaszał je najchętniej wieczorem, w godzinach między 18.00 a 19.00 lub nawet między 19.00 a 20.00. Mówił bardzo krótko, bo zaledwie pół godziny lub tylko 20 minut. Miał też w zwyczaju częste spóźnienia, przekraczające grubo kwadrans akademicki ${ }^{52}$. Mimo to młodzież cierpliwie czekała na niego, wiedząc, że warto. Mało tego „W krótkim czasie wykłady jego doznały takiego powodzenia, że musiano przeznaczyć na nie największą salę. Oprócz studentów z różnych wydziałów uniwersytetu, politechniki i szkoły rolniczej w Dublanach, uczęszczało na nie sporo osób z miasta, m.in. jednym z najgorliwszych słuchaczy był Władysław Studnicki oraz stary profesor, geograf Antoni Rehman, który twierdził, że od 46 lat nie słyszał podobnie świetnych wykładów. Askenazy nie miał daru wy-

50 Pod apelem Przeciwko niedopuszczeniu prof. Askenazego podpisało się osiemdziesiąt osób. Wszystkie nazwiska podano w "Tekach Historycznych" 1960/1961, t. 11, s. 218-219.

${ }^{51}$ Kronika Uniwersytetu Lwowskiego za lata 1898/9 do 1909/10, Lwów 1912, s. $216,279$.

52 S. Górski, Szymon Askenazy, „Świat” 1935, nr 26, s. 4. 
mowy. Mówił powoli, z długimi niekiedy przystankami w pół zdaniu, jak gdyby szukając właściwego słowa, czy określenia, ale wykład był tak opracowany, że można go było bez poprawek posłać do druku" ${ }^{\prime \prime 3}$.

Równie skrupulatnie, jak przygotowywał się do prelekcji, tak zajmował się Askenazy swoimi uczniami. Nigdy nie zaniedbywał tych, którzy zapisali się na jego seminarium. Ci zaś, którzy to uczynili, mieli należeć do najzdolniejszych studentów, owładniętych zamiłowaniem do dziejów najnowszych. Jednym z uczestników tego seminarium był Janusz Iwaszkiewicz, który później w nekrologu Askenazego napisał: „Jako profesor otaczał troskliwą opieką swych uczniów, nie żałował swego czasu na długie konferencje w sprawie podejmowanych prac, udzielając cennych wskazówek, przerabiając niekiedy gruntownie prace idące do druku. Wymagał składania co pewien czas sprawozdań z prac poczynionych, gromiąc niekiedy surowo opieszałych lub dyletantów. Posiadał wielki dar zainteresowania, zapalenia, rozentuzjazmowania do podsuniętego tematu" ${ }^{\prime 4}$.

Z seminarium Askenazego wywodziło się sporo wybitnych później historyków, np.: Adam Skałkowski, Henryk Mościcki, Bronisław Pawłowski, Włodzimierz Dzwonkowski, Marian Kukiel, Emil Kipa, Janusz Iwaszkiewicz. Stworzyli oni z czasem odrębną szkołę historyczną, kontynuując i rozwijając podstawowe założenia naukowe i ideowe profesora. Największym sukcesem szkoły Askenazego było niewątpliwie wydanie, wspomnianych już wcześniej, siedemnastu tomów "Monografii w zakresie dziejów nowożytnych”. Ciekawą opinię o szkole Askenazego sformułował jego uczeń Marian Kukiel: „Co do »Szkoły«; nie należy jej traktować jako dobranego, karnego zespołu. Dobierał się sam przez zainteresowania i zapał badawczy, torując sobie poprzez liczne seminarium drogę do ścisłego grona właściwych uczniów, otaczających po każdym wykładzie Mistrza i często idących z nim na Wysoki Zamek na kwaśne mleko, a także do długich audiencji w jego hotelowym pokoju. A Profesor nie komenderował nami. Zostawiał wiele swobody w określeniu tematu pracy i jego ujęciu. Kierował radą i pomocą jako przewodnik i przyjaciel. Tolerował z naszej strony nawet krytykę, byle nie złośliwą. Była to szkoła niezależnych badaczy. Zespołem była tylko moralnie, w znaczeniu przywiązania dla Profesora (które nie zawsze było trwałe), koleżeństwa (które przetrwało wiele kryzysów) i, co się okazało najtrwalszym, silnie wdrożonego poczucia służby obywatelskiej i moralnej odpowiedzialności historyka" ${ }^{55}$.

Istnienie szkoły Askenazego przypada na lata 1902-1917. Już współcześni uważali, że była ona jednym z najważniejszych przedsięwzięć w polskim dziejopisarstwie ówczesnych lat. Osiągnięcia tej szkoły i jej rozwój można porównać jedynie, zdaniem uczniów Askenazego - Mariana Kukiela i Euge-

\footnotetext{
53 J. Iwaszkiewicz, dz. cyt., s. 894.

54 Tamże, s. 895.

55 M. Kukiel, „Teki Historyczne” 1960/1961, t. 11, s. 307.
} 
niusza Wawrzkowicza, do innego kierunku historycznego wywodzącego się także z Uniwersytetu Lwowskiego, a mianowicie do szkoły Ksawerego Liskego, do której należeli m.in.: Tadeusz Wojciechowski, Oswald Balzer oraz Ludwik Finkel. Wśród zdecydowanie przeważających, pochlebnych opinii o szkole Askenazego, znalazła się jedna krytyczna. Jej autorem był Zygmunt Wasilewski, endek, bardzo nieprzychylnie patrzący na Askenazego. Zarzucał on historykowi, że wszystko, co osiągnął, było wynikiem ogromnych wpływów, które posiadał dzięki przynależności do masonerii. Twierdził też, że „Askenazy stworzył nie tyle szkołę, ile modę. W umysłach utrwaliło się po trochu przekonanie, że dzieje Polski zaczynają się od ks. Józefa Poniatowskiego" ${ }^{\prime 56}$. Osąd ten, mocno przesadzony, nie znalazł jednak zwolenników.

Jeśli chodzi o członków szkoły Askenazego, to najpełniejszą ich listę sporządził Kukiel, podając 32 nazwiska ${ }^{57}$. W literaturze przedmiotu klasyfikuje się je $\mathrm{z}$ reguły $\mathrm{w}$ dwojaki sposób. Po pierwsze, $\mathrm{z}$ uwagi na przynależność polityczną uczniów Askenazego, a po drugie, ze względu na sprawy, którymi zajmowali się oni w swojej twórczości historycznej. Rzadko natomiast podejmuje się próby uszeregowania ich według kryterium kontynuacji lub odrzucenia myśli i ideologii mistrza. Opracowanie takich danych jest dość trudne i wymaga wielu skrupulatnych analiz postaw i dokonań uczniów Askenazego. Niewątpliwie niektórzy z nich zdołali „stworzyć własne szkoły, w których znać, mimo oddalenia w czasie i wszelkie zaszłe odmiany, działanie potężnego impulsu, jaki dał w zaczątku stulecia profesor lwowski swoim uczniom, od którego fala idzie dzisiaj przez trzy już pokolenia" ${ }^{28}$.

Wybuch I wojny światowej położył kres szkole Askenazego i spowodował załamanie tak wspaniale rozwijającej się dotąd twórczości naukowej historyka. Już na początku wojny wyjechał on do Szwajcarii, gdzie w Vevey uczestniczył w pracach Komitetu Pomocy Ofiarom Wojny, na czele którego stał Henryk Sienkiewicz. Działalność Askenazego w Vevey opisał wspomniany już wyżej Zygmunt Wasilewski. Tym razem okazał się jednak znacznie bardziej krytyczny wobec historyka niż poprzednio. Całą swoją energię włożył chyba w to, by udowodnić dwulicowość i fałsz Askenazego. Starał się też wykazać, że Askenazego nie łączyły przyjazne stosunki z pozostałymi członkami komitetu, czyli z Antonim Osuchowskim i Henrykiem Sienkiewiczem. Według niego, miał rzekomo Askenazy prowadzić „politykę żydowską, której nieodzownym warunkiem była propaganda orientacji pro-germańskiej"59. Podobnie jak poprzednio, tak $\mathrm{w}$ tym wypadku Wasilewski był odosobniony w swoich twierdzeniach.

${ }^{56}$ Z. Wasilewski, O jednym z żywotów ginącej epoki, „Myśl Narodowa” 1935, r. 15, nr 28, s. 414 .

${ }^{57}$ J. Dutkiewicz, dz. cyt., s. 190.

58 J. Willaume, Szymon Askenazy, „Przeszłość” 1935, r. 7, nr 12, s. 177.

${ }^{59}$ Z. Wasilewski, Na widowni, „Myśl Narodowa” 1936, nr 51, s. 805. 
Tymczasem Askenazy w okresie funkcjonowania Rady Regencyjnej Królestwa Polskiego wrócił do kraju. Początkowo planował związać się z Uniwersytetem Warszawskim, ale jak wiemy, nie został nań powołany. Dopiero po odzyskaniu niepodległości zaproponowano mu pracę delegata polskiego w Lidze Narodów (1920-1923). Jak Askenazy postrzegany był w tej roli, świadczą wspomnienia osób, które wówczas się z nim zetknęły. Oto jedno z nich: „Askenazy nie posiadał uroku, jakim rozporządzał Paderewski, i nie był lubiany w kołach Ligi. Obawiano się jego kompetencji, gruntownej znajomości zagadnienia i niezłomnej nieustępliwości, gdy chodziło o zasadnicze uprawnienia Polski. Nie był wygodny ani przyjemny w dyskusji. Gdzie Paderewski czarował, Askenazy groził, gdzie jeden prosił, drugi walił w stół pięścią. Potrafił być wspaniale nachalny, prawie bezczelny"60.

Miał być więc Askenazy, według znanych nam relacji, gorąco oddany sprawie polskiej. Jego intencje i postępowanie nieustannie negowali jednak członkowie Narodowej Demokracji. Kiedy w 1923 r. ministrem spraw zagranicznych Polski został endek Marian Seyda, Askenazy podał się do dymisji. Rok później pamiętano jeszcze jego charakterystyczną osobę w Lidze Narodów. Kajetan Morawski, ówczesny polski dyplomata, odnotował w swoich relacjach: „Wspomnienie Askenazego było żywe w Genewie, gdy w 1924 r. przybyłem tam jako minister-rezydent przy Lidze Narodów. W kołach Sekretariatu mówiono o nim z szacunkiem, ale z pewnym retrospektywnym lękiem. Pamiętano, jak ponoszony duchem walki lekceważył nową, ustalającą się nad Lemanem międzynarodową frazeologię i etykietę, jak najbardziej czczonych mędrców ligowego areopagu traktował obcesowo i bezceremonialnie" 61 .

Po powrocie z Genewy do Warszawy Askenazy wyciszył się zupełnie zarówno jako polityk, jak i historyk. Wprawdzie w 1924 r. opublikował kolejną swoją książkę pt. Uwagi, ale napisał ją jeszcze w czasie wojny. Przygotowywał także do druku nowe wydanie Łukasińskiego, ograniczając się w zasadzie do pisywania krótkich artykułów, czego nie można porównać do przedwojennej jego twórczości. Wyrazem bierności Askenazego w ostatnich latach życia była rezygnacja z wygłoszenia inauguracyjnego referatu na V Zjeździe Historyków Polskich w Warszawie w 1930 r. Zgorzkniały i osamotniony zmarł w czerwcu 1935 r. Pochowany został na cmentarzu przy Okopowej.

Los chciał, że jego najbliższa rodzina, żona i córka, nie zdążyły go długo opłakiwać. Wkrótce bowiem wybuchła II wojna światowa, podczas której żona Fenicja ukrywała się pod nazwiskiem Tarkowska w mieszkaniu Wandy Filipowiczowej. Zmarła w 1941 r., a bezpośrednią przyczyną śmierci była podobno operacja wyrostka robaczkowego.

Natomiast o córce historyka Janinie spotkać można dość rozbieżne informacje. Ukazały się one w związku z artykułem Czesława Miłosza Duże

${ }^{60}$ J. Gawroński, Dyplomatyczne wagary, Warszawa 1965, s. 55.

${ }^{61}$ K. Morawski, Tamten brzeg, Londyn 1996, s. 61. 
cienie, opublikowanym w paryskiej „Kulturze” w 1972 r. Miłosz wspomina tam córkę Askenazego jako osobę osamotnioną, mającą zakłócenia zmysłu rzeczywistości, w której dopatrywać się można było początków wręcz klinicznej schizofrenii. Listy, jakie po szkicu autorstwa poety nadeszły do redakcji „Kultury”, napisane przez dwie panie podające się za znajome Janiny Askenazy, potwierdziły i zaprzeczyły jednocześnie relacji Miłosza ${ }^{62}$. Dziś trudno w tej sprawie dociec prawdy. Opierając się jednak na autorytecie poety i bardziej przekonujących wspomnieniach Marii Szabuniewicz, można uznać, że Janina Askenazy faktycznie cierpiała na jakąś chorobę psychiczną. Zmarła zamordowana przez gestapo.

Sam zaś Askenazy przeszedł do historii jako uczony, którego myśli i dokonania warte są utrwalenia i zapamiętania. Odegrał bowiem w swoim czasie, w środowisku historycznym ogromną rolę, której nie sposób dzisiaj zakwestionować. Był pierwszym, który na niespotykaną dotąd skalę rozpoczął na ziemiach polskich badania nad dziejami porozbiorowymi. Nazywany "przewodnikiem niosącym otuchę" nawiązywał zdecydowanie do polskiego oświecenia i romantyzmu, przeciwstawiając się jednocześnie dominacji pozytywistycznego myślenia. Nie bez przyczyny przecież uznaje się Askenazego za czołowego przedstawiciela nurtu neoromantycznego w historiografii polskiej, który przypadł na lata 1900-1918. Dziś wydaje się historykiem nieco już anachronicznym.

\title{
Alina Hinc
}

\section{Szymon Askenazy - szkic do portretu historyka neoromantycznego}

\begin{abstract}
Streszczenie
Niniejszy artykuł ma na celu przybliżenie postaci Szymona Askenazego jako jednego z najpoczytniejszych historyków polskich przełomu XIX i XX w. oraz ukazanie wartości jego dokonań na niwie historycznej. Głównymi wątkami, wokół których toczy się narracja są: czynniki kształtujące postawę naukową Szymona Askenazego, wpływ epoki, w której przyszło mu żyć, na jego twórczość oraz rolę, jaką odegrał w ówczesnym środowisku historycznym. Najkrócej rzecz ujmując, można stwierdzić, że Szymon Askenazy osiągnął na początku XX w. w naukowym życiu polskich elit wysoką pozycję, której nie sposób dzisiaj zakwestionować. Przede wszystkim był pierwszym historykiem, który na niespotykaną dotąd skalę rozpoczął na ziemiach polskich badania nad dziejami porozbiorowymi. Nazywany „przewodnikiem niosącym otuchę" nawiązywał zdecydowanie do polskiego oświecenia i romantyzmu, przeciwstawiając się jednocześnie dominacji pozytywistycznego myślenia. Stąd też uważa się go za czołowego przedstawiciela nurtu neoromantycznego w historiografii polskiej.
\end{abstract}

62 C. Miłosz, Duże cienie, „Kultura” 1972, nr 10/301, s. 19-32; H. Chorążyna, tamże, 1972, nr 12/303, s. 141-142; M. Szabuniewicz, tamże, 1973, nr 3/306, s. 155-158. 


\title{
Szymon Askenazy - sketch to the portrait of a neoromantic historian
}

\begin{abstract}
The article aims to discuss the character of Szymon Askenazy, one of the most read Polish historians of the turn of the 20th century, and to show how valuable his achievements are for history. The narrative revolves around the factors which influenced scientific approach of Szymon Askenazy, the influence of the times he lived in on his work, and the role he played in the historic milieu of his times. In short, one might say that Szymon Askenazy, at the beginning of the $20^{\text {th }}$ century, indisputably achieved a high position in the academic circles of the Polish elites. First of all, he was the first historian in Poland who, to an extent unseen before, started research on the history of Poland before partitions. He was often called "a guide bringing comfort", and he made references to the Polish Enlightenment and Romantic periods, opposing at the same time the dominance of Positivism. Thus, he is considered the main representative of the neo-romantic current in the Polish historiography.
\end{abstract}

